\title{
Asymmetry of Power, Attention, and Reciprocity: Determinants of ROK-China Partnership Diplomacy Failure
}

\author{
Youngjune Chung
}

\begin{abstract}
"Partnership diplomacy" in the study of Chinese foreign affairs has weak theoretical underpinnings and has been defined in a manner insufficiently systematic for middle-range theorizing. Whilst sufficient attention has been paid to determinants of partnership formation, its failure has hitherto received scant attention. To understand this failure, this paper identifies asymmetry of power, attention, and reciprocity as the three major determinants of China's partnership diplomacy failure, generating distorted expectations and prediction uncertainty. Using the ROK-China partnership as a case study, we adopt a conceptual frame from the literature on asymmetric alliances to increase theoretical precision, conceptual clarity, and contextual similarity. We argue that South Korea's naivety about the asymmetries in play and China's overestimation of the ease with which it could leverage the framework to its advantage, ultimately led to collective action dilemmas and mutually exclusive expectations. In conclusion, we incorporate diverse theoretical perspectives more attuned to the actual realities in predicting the future of the bilateral partnership.
\end{abstract}

Key Words: partnership diplomacy, asymmetric partnership, ROK-China Relations

The relationship between the Republic of Korea (hereafter ROK or South Korea) and China in the past decade can be captured in the expression of "same bed, different dreams." The two countries shared certain common interests in economic, trade, and cultural partnerships, but continued to diverge in regional strategic issues. Apparent from their conflicting strategic positions is that the two

\footnotetext{
* Youngjune Chung (rongjun@tongji.edu.cn) is an assistant professor in the School of Political Science and International Relations, Tongji University. He received his Ph.D. in international relations from China Foreign Affairs University. His research interests include international relations theory, China's foreign influence operations, and the ROK-U.S. alliance system.

The views expressed here are those of the author and do not reflect those of Tongji University. This work was supported by the Korea Foundation 2020 Support for Policy-Oriented Research Program
} 
countries' "strategic and cooperative partnership" formation in 2008 failed to cumulate necessary strategic trust to off-set mutual conflict and hostility. ${ }^{1}$ This has defied the common notion in international relations that improvements in economic, trade, and people-to-people exchanges have a positive effect on enhancing political-strategic relations.

So why has the strategic cooperative partnership yielded less-than-expected results? Existing studies have pointed to the incompatibility in visions of economic and political order and its regional arrangement as a key factor in ROK-China strategic partnership failure. China's increasing hegemonic ambitions and dissatisfaction with its position in the international system, for instance, pose a central challenge to the U.S. hub-and-spokes system, with increases in conflict potential between the ROK and China as side-effects (Legro 2007). Indeed, China as a rising power has complicated and polarized the region, with its own idea of a global order, characterized by economic globalization, political multipolarity, and a new type of major power relations (Ministry of Foreign Affairs of the PRC 2019; Global Times 2019; Lampton 2013). Others have attributed to the evolution and change in distribution of ideas as a source of bilateral partnership failure. For example, South Korea and China's shared identity of economic rationality and regional community, which propelled their normalization in 1992, began to disintegrate since the U.S. economy began a broad decline in 2008. As a result of China's relative surge in the international political system, their once shared norm for shelving disputes, promoting stable relationships, and engaging in extensive people-to-people intercourse slowly started to wane off, while China's foreign policy preferences and identity were strongly reconstructed, now exerting a more assertive role abroad, with expanded and diversified global agendas. Its increased assertiveness in regional geopolitical issues since then has reinforced ROK's speculation that China could potentially be a revisionist power, intended on rewriting the rules of the international system (Gilpin 1981; Friedberg 2005; Johnston 2013; Liao 2016). In addition, the persistence of "collective historical memory," "parochial nationalism," and subsequent cognitive dissonance also suggested a "gloomy outlook" for the future of ROK-China bilateral relations, under the rubric of "intra-regional cooperation" (Moon and Suh 2007). For the ROK and China, then, it was inevitable that evolving conflicts regarding norms and identities would prevent any sort of strategic cooperation and partnership enhancement.

\footnotetext{
${ }^{1}$ In 2013, the two countries concurred on the need to "enrich" the strategic cooperative partnership. In 2017, they decided to "upgrade" the partnership to a "new height" (The Blue House 2017).
} 
Despite the credibility of existing arguments on ROK-China strategic partnership failure based on diverging identities and structure of the international system, the extant literature has not yet adequately provided a conceptual framework that incorporates the factors of asymmetry in bilateral power and attention, as well as the lack of cooperative mechanism as independent variables to understand strategic partnership failure. Against this backdrop, we begin by conducting a meta-theoretical reflection on the concept of partnership diplomacy, based on Western and Chinese theoretical perspectives, as well as policy relevance. We then formulate a comparative framework for asymmetric partnerships juxtaposed with a framework of asymmetric alliances, which enables the exploration of the structural design and underlying logic of China's partnership diplomacy. Next, we turn to the ROK-China strategic partnership as case study. The ROK represents a good case study for generalizing (asymmetric) strategic partnerships as China has a comparative advantage in the production of almost all forms of strategic public goods vis-à-vis South Korea. Last, we review the ROK-China strategic partnership from a theoretical perspective in order to incorporate diverse epistemological perspectives more attuned the reality in predicting the future of bilateral relations.

\section{SETTING THE STAGE: META-THEORETICAL RATIONALES FOR CHINA'S STRATEGIC PARTNERSHIP FORMATION}

After establishing its first strategic partnership with Brazil in 1993, China built multiple comprehensive partnership frameworks with more than 100 countries and regional organizations by mid-2018. ${ }^{2}$ These include: (1) natural allies such as Russia (comprehensive strategic partnership of coordination) and Pakistan (all-weather strategic cooperative partnership); (2) territorial disputants such as India (strategic and cooperative partnership for peace and prosperity), Indonesia (comprehensive strategic partnership), Malaysia (comprehensive strategic partnership), and Vietnam (comprehensive strategic cooperative partnership); (3) western European nations such as France (comprehensive strategic partnership), the UK (comprehensive strategic partnership), and Denmark (comprehensive strategic partnership); (4) the African nations of Algeria (comprehensive strategic partnership) and Nigeria (strategic partnership); and (5) the United States (constructive strategic partnership). The full list span great,

\footnotetext{
${ }^{2}$ The author's compilation is based on multiple media sources and the Ministry of Foreign Affairs of China website.
} 
middle, and small powers with vastly different properties; for example, it includes resource-rich and resource-poor nations; natural allies and potential enemies; geopolitical, diplomatic, and economic assets and liabilities; democratic and autocratic nations; and failed states and thriving economies. Thus, it is unclear what measurable criteria, if any, meet the Chinese definition of 'strategic partners.'

The majority of the extant literature on this topic have focused on the effects of China's strategic partnership diplomacy, mainly in three aspects: (1) routinization of official visits between top leaders and the military establishment, (2) long-term goals based on common interest, and (3) cooperation on political and non-traditional security issues (Deng 2007; Kim 2008; Kim 2012; Lee 2013; Hwang 2014; Michalski and Pan 2017). With regards to determinants of partnership choice, Evan Medeiros argues that partnership diplomacy allows China to set the "scope, content, and pace of engagement" in bilateral relations and that "this logic explains the eclectic variety of states, groupings of states, and multilateral organizations with which China has established such strategic partnerships" (Medeiros 2009, 85-86). Medeiros, however, does not elaborate on China's strategic and diplomatic objectives for formulating specific frameworks. Quan Li and Min Ye argues that the Chinese government's choice to "build such an elaborate network is not random" and that it is largely determined by the 1) need to counter the U.S. pressure; 2) necessity of maintaining peace and stability along its borders; and 3) achieving the long-term goal of modernization (Quan and Min 2019). Still, their analysis does not account for the diverse partnership agreements in existence, including countries that are American treaty allies, as well as with developing countries deemed less important for security or economic modernization. Furthermore, it does not provide accounts of why some key partnerships reap less than expected results compared to others. Sun Degang, a professor at Fudan University, on the other hand, argues that capability (economic strength, regional influence, political stability) and willingness (economic interdependence, political friendliness) account for China's selection of partnership formation and the variation in its degree and level of intimacy across different countries (Sun 2020a, 30-31). However, established middle powers such as South Korea, who enjoy relative superiority in all five of the categories can be ranked merely third in the five-tier system of partnership category according to this categorization. ${ }^{3}$ In another article, Sun groups

3 Tier 5 - all weather strategic partnership; Tier 4 - comprehensive strategic cooperative partnership; Tier 3- strategic and cooperative partnership; Tier 2 - comprehensive strategic partnership; Tier 1 - strategic partnership. 
countries in the Middle East into four categories, that serves as a reference point for China's partnership classification across the board: 1) pivot states (regional powers with comprehensive strength who function as pivots or hubs in China's global partnership network); 2) node states (partners that enjoy a particular special status, serving as bridges to facilitate cooperation between China and other great powers); 3) key states (medium-sized powers that have relative economic mass and development potential and which can exert influence on their neighboring countries); and 4) stronghold states (partners which are relatively small in terms of their size, population, and economic volume but which nonetheless exhibit a high degree of friendliness toward China and have a strong desire for bilateral economic and trade cooperation) (Sun 2020b). However, this classification is less than useful in verifying individual countries' position in China's hierarchy of partnership types, as many of the states' status, capability-wise, can be categorized as a pivot state, a key state, or a stronghold state. Georg Struver, a research fellow at the GIGA Institute of Asian studies, meanwhile, argues that 1) economic interests, 2) ability to provide markets and natural resources, 3) increase of bargaining power in international negotiations, and 4) increase of the legitimacy of Chinese foreign policies account for determinants of China's partnership selection (Struver 2017). Again, such an account does not answer why fragile states such as Pakistan are placed at the top in the partnership pyramid, further accentuating the complexity of conceptual operationalization. Taken together, a cursory review of the existent literature points us to the main issue addressed by this paper, namely, what determines strategic partnership failure. (Dittmer 1999; Wilkins 2012; Chidley 2014; Zhou 2017; Wu 2018).

From the Chinese policy perspective, the concept of strategic partnership emerged since the 1990s to "make friends" and create a "new type of international relations," that could guarantee a benign environment for its rise (Liu, Cui and Xiao 2019). The rationale is contrary to the history of Western power politics, characterized by domination and exploitation, and accounts for why Chinese foreign minister Wang Yi has asserted for "abandoning old and outdated concepts of international relations" and advancing greater "partnerships" in the "new international situation and epoch trend" (Ministry of Foreign Affairs of the PRC 2016). The innate problem in such a proposition by the Chinese, however, has been concerns over perceived attempts by the Chinese leadership to assert a greater voice and role in international affairs, to the detriment of liberal order and values, and in ways that potentially disadvantage smaller states. For example, Avery Goldstein advances the argument that strategic partnerships maximize China's "own leverage and flexibility" and binds other states and group of states' 
"interests to China's," which ultimately increases the "costs [other states in a partnership] face if they took actions that ran contrary to China's interests" (Goldstein 2003, 74). Furthermore, such an imperceptible ambition is seen to be achieved by "muting disagreements about domestic politics" in the "interest of working together on matters of shared concern in international diplomacy" (Ibid, 75). Such an affirmation is congruent with China's official discourse, for instance, in former Chinese Premier Wen Jiabao's description of strategic partnerships as "transcending differences in ideology and social system, and non-subject to the impacts of individual events that occur from time to time." (Mission of the PRC to the European Union 2014). However, whether by coincidence or by design, their assumptions of strategic partnerships are identical to the basic assumptions of political realism, which rejects the operation of variables at the unit and state level of analysis. Muting disagreements about domestic politics and transcending differences in ideology and social system is problematic, however, in that it can be perceived as a form of coercion and assertiveness from the minor power's perspective. In contrast, the major power can enjoy a certain degree of strategic flexibility and plausible deniability due to the ambiguities and vagueness involved in the concept.

Taken together, the problem of conceptualizing partnership diplomacy can be said to be compounded by a lack of consensus over its scope and content, which then makes the understanding of its failure more difficult. Against this backdrop, this section attempts to provide a broad frame of reference to attribute (asymmetric) partnership failure, by juxtaposing it against the conceptual framework offered by the literature on asymmetric alliances. The rationale is threefold.

First, although partnership frameworks are said to be non-institutional without a binding system to regulate state behavior, they are often identical in logic from traditional alliance-building efforts. For instance, despite Chinese claims to seek “partnership without alignment” (结伴不结盟), in defiance of “zero-sum, Cold War mentality, directed at a third-party" (Xinhua 2014), its formation of a strategic partnership with Russia in 1994 was regarded as an emergent product "amidst sharpening Sino-Russian concerns about U.S. international dominance in Europe and Asia (NATO's eastward expansion; Washington's recommitment to a broad security role in the Western Pacific as well as the March 1996 aircraft carrier maneuvers demonstrating an enduring unofficial U.S. support for Taiwan) (Goldstein 2003, 75). In this vein, we cannot entirely rule out the possibility of partnership diplomacy, even if "informal in nature," as being completely devoid of "threat-driven" goals (Wilkins 2008). Second, from a historical perspective, strategic partnership diplomacy, characterized by frequent exchange of official 
visits and principles of mutual respect and non-interference, is not the first instance of such inter-state arrangement actively initiated by the Chinese. The ancient "tributary system," for example, similarly provided China and other minor actors an "overarching framework for organizing external relations" and a "set of rules and institutions" to regulate "foreign diplomatic relations [and] social and economic interaction * i in early modern East Asia” (Kang 2010, 81). In such a system, as Yuen Foong Khong notes, the "general pattern" of Chinese external policy was to demonstrate "benevolence and non-coercion toward tributaries" (i.e., institutionalized partners with a high level of intrinsic value) and "a willingness to employ force and coercion against non-tributaries" (i.e., under-institutionalized partners who refuse to respect your power, status and ideas) (Khong 2013, 27). If such a line of historical continuity still holds, it can account for why U.S. allies such as South Korea, Japan, and Australia, despite their seemingly strong strategic partnerships with China, have often been victims of Chinese sanctions and the threat of sanctions. Therefore, according to the historical and behavioral logic, small states in China-led strategic partnerships can suffer the same pitfalls in traditional asymmetric alliance networks, such as limited autonomy and fear of abandonment (Liu and Liu 2017, 160). Third, despite the fact that the "common threat" factor is dropped off in strategic partnerships, and cooperative disposition toward alignment is premised, these partnership frameworks can serve as a vehicle for China to manipulate and advance its parochial ambitions and objectives, against the interests of smaller states. The loose and unpredictable level of mutual binding, and the lack of a mechanism to resolve contentious bargaining, both of which are key to sustaining a healthy alliance relationship, can favor the strong over the weak in any "strategic relationship," resulting in limited flexibility and maneuverability for the small states.

Against this backdrop, we conduct a brief analysis of asymmetric alliance and strategic partnership comparison in the next section, in order to extract some potential sources of the latter's failure.

\section{ASYMMETRIC ALLIANCE AND STRATEGIC PARTNERSHIP: A COMPARISON}

Throughout history, states have formed alliances to guarantee their security and survival, and remedy profound constraints under the anarchical international system (Powell 1999; Grieco 1988; Fearon 1998). Originally, alliances were designed to be mutually beneficial, reciprocal, and equally based in operation. 
However, in an asymmetric relationship, alliances have tended to be static and rigid, reflecting "patron-client" relationships, in which the bargaining revolved around the trade-off between "autonomy and security" in lieu of "entrapment and abandonment" (Snyder 1984, 465-467). In the alliance relationship, the minor power viewed the membership as a critical component for protection, while the major power viewed its value to the extent that "common perceptions of threat, shared strategic objectives, diplomatic attention, shared values, and common history" were presented (Vaughn 2007). Likewise, alliances have reduced opportunism and rendered each side's interests more or less mutually complementary (Table 1). In this regard, James Morrow argued that asymmetric alliances, in particular, are "easier to form and last longer than symmetric alliances" since they aim to complement mutual benefits, which then provides incentive for each side to uphold their end of the agreement (Morrow 1991, 904).

Table 1: Conceptual Framework of Asymmetric Alliance

\begin{tabular}{c|c|c|c|c}
\hline Study Category & Power status & Relationship & $\begin{array}{c}\text { Mechanism for } \\
\text { cooperation }\end{array}$ & $\begin{array}{c}\text { Framework for } \\
\text { conceptualization }\end{array}$ \\
\hline \multirow{4}{*}{$\begin{array}{c}\text { Asymmetric } \\
\text { alliance }\end{array}$} & Major power & $\begin{array}{c}\text { Does not see } \\
\text { partner as } \\
\text { significant other }\end{array}$ & Transaction & $\begin{array}{c}\text { Interest-based } \\
\text { policy issue }\end{array}$ \\
\cline { 2 - 5 } & Minor power & $\begin{array}{c}\text { Sees partner as } \\
\text { significant other }\end{array}$ & $\begin{array}{c}\text { Fear of } \\
\text { Abandonment }\end{array}$ & Linked to security \\
\cline { 2 - 5 } & $\begin{array}{c}\text { Interaction } \\
\text { outcome } \\
\text { between } \\
\text { status-quo and } \\
\text { revision }\end{array}$ & $\begin{array}{c}\text { Benefits are } \\
\text { mutually } \\
\text { complementary }\end{array}$ \\
\hline
\end{tabular}

Source: Edited from Gi-Wook Shin, One Alliance, Two Lenses: U.S.-Korea Relations in a New Era (Stanford University Press 2010), pp. 10.

What implications can we draw from the asymmetric alliance framework for China-led strategic partnerships? Building upon previous discussions, we argue that China's partnership diplomacy reveals three outstanding constraints: one, the negligence of asymmetry in power, and two, the negligence of asymmetry in attention, and three, the negligence of asymmetry in reciprocity, that is, lack of reciprocal mechanisms to deter cheating and impose penalties, that could potentially off-set the former's impacts.

\section{THREE SOURCES OF STRATEGIC PARTNERSHIP FAILURE}

First, neglecting to account for asymmetry and symmetry in power presents 
serious flaws for interdependence and reciprocal interactions in strategic partnerships as unequal distribution of power can cause unequal distribution of expectations between major and minor states. Tang Shiping points out that "asymmetric distributions of power" are an "important material regulator" of state interactions and "provide some much-needed insight into how to manage the relationship between a great power and its smaller neighbors" (Tang 2009, 621). Brantly Womack also notes that "disparities in capacities create systemic differences in interests and perspectives between stronger and weaker sides" (Womack 2006, 17). In other words, failing to account for asymmetry in power can be a recipe for strategic partnership failure due to its effect on preference diversification. A natural logic from such consequences is that interaction between the minor power and major power will evolve into a phase where the former has but to "adapt their domestic circumstances to the strategy that their foreign environment dictates" and offer more concessions to the major power (Snyder 2013, 317-318). In many cases, however, policy adaption, or identity change, is an arduous task for the minor power, likely leading to a Pareto-inferior outcome of mutual non-cooperation and relational friction, and even "unintended consequences" of offending the major power (Jervis 1999). In contrast, the major power's frustration can be aggravated by the fact that it has less than expected leverage to adjust its partner's policies in line with its national interests.

Second, Shin Gi-wook argues that "smaller states pay the majority of attention to bilateral diplomacy" while bigger states "lack the time and capacity to devote as much attention to the relationship," leading to an asymmetry of attention to prevail among interdependent states under anarchy (Shin, Izatt and Moon 2016, 3). In this vein, the source of strategic partnership failure lies not so much in asymmetry of information, commitment, or enforcement, as Powell, Grieco and Fearon would argue, but rather lopsided attention between small states and larger states. Asymmetric expectations in attention, for example, can exacerbate misperceptions, reduce bargaining ranges, and widen conflict between the major and minor power, potentially leading to discord. Heightened misunderstandings will eventually lead the strategic partnership to drift away from a state of status quo to a state of separation (i.e., decoupling, sanctions, balance of power) or even disarray (i.e., violent protests and exhibitions of nationalism).

Third, a lack of reciprocal mechanisms due to its unbinding and voluntary nature makes it difficult to enmesh each party in collective expectations, resulting in strategic partnership failure. Robert Keohane notes that without "enforceable legal liabilities" that can deter selfish behaviors, partnerships provide strong incentives for states (in particular, major ones) to exploit their partner in the short term (Keohane 1982, 154). Jong Kun Choi and Chung-in Moon 
also notes that "in an unstable system, actors have strong inclination to defect, namely not cooperating with others but seeking to change the status quo" (Choi and Moon 2010, 354). Such has been one of the defining problems in China's strategic partnership diplomacy, and stands in contrast to asymmetric alliances, that can resolve collective action dilemmas and information costs of uncertain mutual intentions through treaties, interlocking organizations, joint management responsibilities, and mutually recognized standards and principles (Ikenberry 2000, 41).

In short, the three problems of asymmetry in power, attention, and reciprocity ultimately resulted in high initial hopes to end in disappointment. Indeed, China's partnership frameworks over the years, have failed to "deepen strategic mutual trust with partners, and have been incapable of dispelling countries' [such as Japan, Australia, and South Korea's] growing cloud of strategic suspicion toward China, nor has it prevented them from engaging in activities harmful to China" (Zhang 2016, 44). Further, it has not stopped these countries from augmenting American military presence on their soil to counter China's military rise.

Against this background, we test the three aforementioned sources of partnership failure to the case study of ROK-China strategic partnership in the following section.

\section{ROK-CHINA STRATEGIC PARTNERSHIP: SAME BED, DIFFERENT DREAMS}

A cursory review of the existing literature confirms that our general assumptions on strategic partnership failure can be applied to explaining ROK-China strategic partnership failure.

First, the asymmetry in power plays a strong force in ROK-China strategic partnership failure, against the backdrop of China having the comparative advantage in all tangible categories vis-a-vis South Korea. Economically, for instance, China accounted for 26.8\% of ROK's total exports in 2019, and 34.4\% when combined with Hong Kong (Ministry of Trade, Industry and Energy of the ROK 2020). Conversely, China's trade dependence on South Korea, in terms of exports was only 4.4\% in 2018. (Korea International Trade Association 2020). As many Korean national think tanks have continuously warned, the context of ROK's deepening economic interdependence toward China entails potential strategic uncertainties, distrust, anxieties and can even create vulnerabilities, 
demonstrated by China's imposition of a rare-earth materials embargo on Japan in 2010 and sanctions for THAAD installation from 2017 (Song 2020; Korea Chamber of Commerce and Industry 2020; Ryu 2020). In the same vein, distribution of power is also highly in favor of China in terms of military power, with China showing superiority in all categories of strength, from manpower and defense expenditure to number of total aircrafts, on top of having a full nuclear triad (Table 2).4

Table 2: Military Strength Comparison: ROK and China (2018-2020)

\begin{tabular}{|c|c|c|}
\hline & South Korea & China \\
\hline Active Personnel & 625,000 & $2,183,000$ \\
\hline Defense Budget & US \$38B & US \$224B \\
\hline Total Aircraft & 1,614 & 3,187 \\
\hline Fighters & 406 & 1,222 \\
\hline Attack Aircraft & 466 & 1,564 \\
\hline Attack Helicopters & 112 & 281 \\
\hline Tank Strength & 2,654 & 13,050 \\
\hline Total Naval Assets & 166 & 714 \\
\hline Submarines & 16 & 76 \\
\hline Marine Strength & 1,907 & 4,287 \\
\hline Nuclear Warheads & 0 & 290 \\
\hline $\begin{array}{l}\text { Ballistic Missile } \\
\text { Arsenal }\end{array}$ & $\begin{array}{l}\text { LACM, } \\
\text { SRBM, } \\
\text { Cruise Missile }\end{array}$ & $\begin{array}{c}\text { ICBM (180-220), SLBM (28-44), } \\
\text { SRBM (150-200), } \\
\text { IRBM, MIRV, HGV, } \\
\text { ASBM, Cruise Missile }\end{array}$ \\
\hline $\begin{array}{l}\text { Missile Defense } \\
\text { Options }\end{array}$ & $\begin{array}{c}\text { PAC-2, PAC-3, M-SAM (2), } \\
\text { L-SAM }\end{array}$ & $S-300, S-400$ \\
\hline
\end{tabular}

Against this backdrop, it can be inferred that asymmetry in power between South Korea and China can be said to be a key source of bilateral strategic partnership failure, especially surrounding issues of responsibility and burden-sharing. For instance, for the ROK, denuclearization and re-unification of the Korean Peninsula is a given national strategic objective, but is also a public

\footnotetext{
${ }^{4}$ Comparison results of world military strengths for ROK and China from 2018 to 2020 show wide disparities in the areas of: active personnel, defense budget, total aircraft, fighters, attack aircraft, attack helicopters, tank strength, total naval assets, submarines, marine strength, nuclear warheads, ballistic missile arsenal, and missile defense options. See: GlobalFirepower.com, https://www. globalfirepower.com/countries-comparison.asp; Hans M. Kristensen, "China's New DF-26 Missile Shows Up at Base in Eastern China," Federation of American Scientists, January 21, 2020, https://fas.org/category/china/; Missile Defense Project, "Missiles of South Korea," Missile Threat Center for Strategic and International Studies, June 14, 2018, https://missilethreat.csis.org/country/ south-korea; Missile Defense Project, "Missiles of China," Missile Threat Center for Strategic and International Studies, June 14, 2018, last modified January 13, 2020, https://missilethreat.csis. org/country/china.
} 
good in terms of global security, and has tended to view China as having the obligation to share the burdens and responsibilities for solving the strategic conundrum. Put differently, South Korea has tended to view China's political, economic, and military resources and clout as excludable goods, the benefits of which partners like itself should rightly enjoy within a strategic framework. Conversely, China's key concern regarding this issue has been whether the expected payoffs from such burden-sharing exceeds the expected value of the costs incurred. As Randell Schweller notes, a state's choice is "motivated by opportunities for gain ' ' and appetite" (Schweller 1994, 79), and having more "attractive alternatives and consequently with lower losses" makes major powers such as China to claim "a larger share of the value being distributed" within the partnerships (Hopmann 1996, 119). China, therefore, having more global resources and less bilateral dependence on the ROK, unbalances the reciprocal trade-off barrier in its favor, while lesser alternatives and greater losses associated with strategic partnership failure puts the ROK in a more vulnerable position than China does. The logical conclusion that we make from here is that unlike asymmetric alliances, the mutual benefits of closer ties are not so obvious under partnerships of asymmetric power. Most importantly, the partnership frameworks do not provide sufficient incentives, in the long run, for major powers like China to make appropriate trade-offs for minor powers on issues of strategic value.

Second, the asymmetry in attention also plays a strong explanatory variable in ROK-China strategic partnership failure. For instance, China remains wary of the configuration of power in Northeast Asia shaped by American strategic engagement and the continued presence of US forces in Korea (USFK), which is viewed as a critical source of "security dilemma" and "regional interference." (People's Daily 2018). The Chinese have historically viewed the American forward presence in Northeast Asia as being aimed at deterring its rise (Chung 2012). For the ROK, on the other hand, the military alliance is a critical component of security and provides the rationale to improve missile defense and reception staging, onward movement, and integration (RSOI). As a result, control of the security dilemma can be easily lost under anarchy, and a security spiral can continue unabated. China claims that the problem of U.S. forward presence is a function of South Korea's sovereignty and self-determination; whereas the ROK is more concerned about utilizing the alliance for protection, and also a variety of purposes, including a balanced "butter-gun trade-off", and expanding the horizon of its diplomacy. ${ }^{5}$ In this respect, the factor of asymmetry in attention

${ }^{5}$ In macroeconomic terms, the "guns versus butter model" demonstrates the relationship 
leads to mutually exclusive expectations and perceptual gap between the ROK and China, that will continue to lead both parties toward distrust and conflict in the partnership (Chung 2011; Li 2016; Chung 2017; Dong 2019). In addition, the hostile external environment that North Korea has dictated for 30 years in Northeast Asia has also divided the Chinese and South Koreans' attention on how to deal with the nuclear blackmail. Yan Xuetong at Tsinghua University, argues that the common threat of North Korea's development of nuclear weapons and the mutual interest of fostering regional stability provide a fertile ground for China and the ROK to forge a military alliance (Yan 2013). Conversely, Hwee Rhak Park, argues that China and the ROK "do not have a serious common threat to unite them, do not share common security interests and do not trust each other (Park 2015)." Such diversifying attention and perception over material threats, such as nuclear weapons, evidently constitute a structural impediment to fostering the China-ROK strategic partnership.

Third, as mentioned above, whether minor powers such as ROK demonstrates a commitment to reciprocal steps, or has communicated on what it is willing to trade in exchange for the strategic support of the major power, is significant to the extent that enforcing reciprocal bargaining based on same trade-off principle and exploring more attractive alternatives with lower costs becomes a logical choice for the major power. For example, with regards to the same trade-off principle in North Korea's denuclearization, South Korea can induce China's full-fledged support and shift its policy choice from individual to collective action should the fate of the following issues are addressed in line with Chinese interests: (1) USFK; (2) U.S. nuclear umbrella; and 3) United Nations Command (UNC). (Chung 2019; Lee and Chung 2020). Likewise, Chinese support for Korean re-unification, would require the ROK government to provide a clear blueprint on the following: (1) the political, economic, and normative benefits of re-unification for China, and (2) a vision of a unified Korea allied to China (Chen 2018; Fukao, Tomohiki and Kwon 2017; Deng 2013; Zhan and Lee 2012). In this regard, greater strategic cooperative partnership facilitation between the ROK and China requires symmetric and reciprocal cooperative mechanisms that can guarantee mutually beneficial arrangements (Kavalski 2018, 236).

In short, asymmetry in power and attention, and lack of reciprocal mechanisms has and serves as triggers in producing strategic miscalculation and

between a nation's investment in defense and civilian goods, and it serves as an analogy for choices between defense and civilian spending. The military alliance and American extended deterrence help to divert national funds away from spending in defense to health, education and social welfare programs. This consideration for a balanced trade-off is overlooked by China, which views the alliance as a function of sovereignty and self-determination. 
misperception between South Korea and China. Some other salient elements with strategic implications for the bilateral partnership that requires further attention to the three asymmetries are summarized in table 3 below.

Table 3: South Korea and China's Positions on Regional Strategic Issues

\begin{tabular}{|c|c|c|}
\hline Components & South Korea's Position & China's Position \\
\hline $\begin{array}{l}\text { North Korea's } \\
\text { Nuclear } \\
\text { Program }\end{array}$ & $\begin{array}{l}\text { 1. Denuclearization in line with the } 1992 \\
\text { Joint Declaration } \\
\text { 2. International Community Should Work } \\
\text { Together } \\
\text { 3. Military Confidence Building Is Required }\end{array}$ & $\begin{array}{l}\text { 1. "No War, No Instability, and No Nukes" } \\
\text { on the Peninsula } \\
\text { 2. US' Threat and Hostile Policy Is Root } \\
\text { Cause } \\
\text { 3. Dissolve Cold War Structure and Establish } \\
\text { a Peace Regime }\end{array}$ \\
\hline $\begin{array}{l}\text { Engagement } \\
\text { Policy with } \\
\text { North Korea }\end{array}$ & $\begin{array}{l}\text { 1. Economic Projects as Rewards for } \\
\text { Denuclearization } \\
\text { 2. Creation of a Single Economic Community } \\
\text { as Guarantee for Reform }\end{array}$ & $\begin{array}{l}\text { 1. Supports North Korea's "New Strategic } \\
\text { Line" } \\
\text { 2. Supports North Korea's Adoption of } \\
\text { Socialist-Market Economy Model }\end{array}$ \\
\hline $\begin{array}{l}\text { Unific } \\
\text { the K } \\
\text { Pen }\end{array}$ & $\begin{array}{l}\text { 1. No Intention of Seeking North Korean } \\
\text { Regime Collapse or Unification by } \\
\text { Absorption } \\
\text { 2. Must Prepare for North Korean Contingency } \\
\text { in Times of Peace }\end{array}$ & $\begin{array}{l}\text { 1. Supports Peaceful Unification Between } \\
\text { the Two Koreas } \\
\text { 2. Stability More Important than Radical } \\
\text { Unification } \\
\text { 3. Unofficially Supports the North Korean } \\
\text { Regime }\end{array}$ \\
\hline $\begin{array}{l}\text { US } \\
\text { Kore }\end{array}$ & $\begin{array}{l}\text { 1. US Forces are Bedrock for Stability on } \\
\text { the Peninsula } \\
\text { 2. Should Continue Troop Presence } \\
\text { Post-Unification }\end{array}$ & $\begin{array}{l}\text { 1. Must Consider North Korea's Security } \\
\text { and Development Problems } \\
\text { 2. Opposes the Alliance Evolving into } \\
\text { Playing a Regional Role }\end{array}$ \\
\hline $\begin{array}{l}\mathrm{N} \\
\mathrm{D} \\
\mathrm{S}\end{array}$ & $\begin{array}{l}\text { orth Korea's Nuclear and } \\
\text { ations } \\
\text { Sovereign Matter }\end{array}$ & $\begin{array}{l}\text { ional Security Dilemma } \\
\text { Anti-China Containment } \\
\text { lal States }\end{array}$ \\
\hline $\begin{array}{l}\text { North } \\
\text { Def }\end{array}$ & $\begin{array}{l}\text { 1. Should Not Be Repatriated Back to North } \\
\text { Korea } \\
\text { 2. China's Practice Is Against International } \\
\text { Norms } \\
\text { 3. Should Be Granted Refugee Status in } \\
\text { Line with UN Convention Against Torture }\end{array}$ & $\begin{array}{l}\text { 1. Defectors are Economic Migrants } \\
\text { 2. Issue Pertains to China's Sovereignty, } \\
\text { Territory, and Ethnic Minority } \\
\text { 3. Bilateral Issue Between China and North } \\
\text { Korea }\end{array}$ \\
\hline $\begin{array}{l}\text { Six Party } \\
\text { Talks and } \\
\text { Peace Treaty }\end{array}$ & $\begin{array}{l}\text { 1. Limited Utility Due to Inter-Korean } \\
\text { Disagreement and US-China Power } \\
\text { Game } \\
\text { 2. China Should Do More }\end{array}$ & $\begin{array}{l}\text { 1. China Is Signatory to Armistice Treaty } \\
\text { 2. Should Evolve into a Regional Security } \\
\text { Mechanism } \\
\text { 3. Platform to Maximize National Interests } \\
\text { and Balance US Influence }\end{array}$ \\
\hline $\begin{array}{c}\text { Territorial } \\
\text { Dispute }\end{array}$ & $\begin{array}{l}\text { 1. Chinese Military Aircraft Should Not } \\
\text { Enter the Korea Air Defense Identification } \\
\text { Zone (KADIZ) Without Prior Notice } \\
\text { 2. EEZ: "Median Line" Principle \& } \\
\text { Continental Shelf } \\
\text { 3. South Korea Effectively Controls leodo }\end{array}$ & $\begin{array}{l}\text { 1. EEZ: "Natural Prolongation" of Land Territory } \\
\text { 2. Suyan Rocks: Chinese Jurisdiction / Falls } \\
\text { under Chinese Air Defense Identification } \\
\text { Zone }\end{array}$ \\
\hline
\end{tabular}

Finally, in conclusion below, we assess the future of ROK-China strategic cooperative partnership by incorporating diverse theoretical perspectives. 
Incorporating different paradigms can provide a platform for understanding the real world, provide theoretical guidance for resolving inter-state stalemates, and ultimately enhance bilateral relationships.

\section{CONCLUSION}

China's partnership diplomacy and the signing of strategic frameworks has often been hailed as a ground-breaking diplomatic achievement for China and its partners. Against this backdrop, we have argued that the framework's conceptual vagueness and lack of clarity have resulted in a widening gap between reality and each countries' predictions for the partnership, and that the underlying causal variable at work was the three factors of asymmetry in power, attention, reciprocity.

In particular, the concept has been a liability for the ROK-China strategic cooperative partnership because it often led to distorted expectations and amplified divergences. It is in this regard that we have argued that the minor power's naivety about the asymmetries and the major power's overestimation of the ease with which it could leverage the framework to its advantage ultimately led to collective action dilemmas and mutually exclusive expectations. In other words, the concept's weak theoretical foundation and inappropriate application by China and its partners produced mutual cognitive dissonance and discord. To be successful in this regard, strategic partnership frameworks should focus on increasing mutual understanding while enhancing each sides' commitments in a mutually beneficial way, while the three determinants of partnership failure should be corrected to achieve a better outcome.

First, the problem of asymmetry in power can be relieved by regular and fluid exchange of information, especially on issues of military and political concern. This can provide significant progress in reducing distrust and can be an efficient way for the two partners to find a bargaining range on issues of potential conflict. Partners can incrementally integrate each sides' communications and information-sharing practices, while also deepening an understanding of each other's strategic decision-making systems. The objective of partnerships then should be oriented towards confidence-building, reducing uncertainty in times of crisis and conflict, and minimizing the likelihood of undesirable, unintended outcomes. Integrative bargaining methods that make each side's preferences and interests explicit and that make the relationship more adaptable to changing circumstances are preferable to the more adversarial distributive bargaining 
methods that are commonplace under anarchy.

Next, the problem of asymmetry in attention can be solved by expanding the scope of common interests that can guarantee cooperation between states. As mentioned earlier, the presence of shared interests alone, has been a precarious basis for international cooperation in Northeast Asia, as defection often prevailed even in the presence of shared interests. Despite common interests in denuclearization and conflict prevention on the Korean Peninsula, for instance, the logic of anarchy continued to operate with dominant force in the interactions between China and South Korea (Ministry of Foreign Affairs of the ROK 2018). Against this backdrop, the strand advocating "liberal transition" projects, in which "strengthening liberal elements such as economic interdependence" is still believed by many, including the incumbent administration in Seoul, as an effective way "to more pacified and predictable interactions among states" in the region (Choi 2015, 294). In addition, the constructivist approach of creating an epistemic, knowledge-based community with authoritative claim to policy-relevant knowledge can be useful in mitigating the problem of asymmetry in attention (Checkel 1999). For example, creation of an epistemic community between the two countries can shape a set of shared, principled beliefs, professional judgment, common notions of validity, and common policy enterprises (Haas 2005, 3) to hold ground. Technical issues of mutual concern such as maritime delimitation, fisheries and resource protection, history, the environment, and high-tech weapon acquisition, which have plagued ROK-China strategic cooperation, can be alleviated in such a community through provision of objective standards that could be used for integrative bargaining. Through inquiries regarding weapon specifications and functions, misunderstandings, misperceptions, and mutual distrust between the countries can also be mitigated. To illustrate, some of the strategic assets supplied to South Korea by the U.S. (and which disturb Chinese security) are defensive weapon systems (particularly THAAD). Distinguishing between offensive and defensive weapons can help states avoid security spirals (Jervis 1978). Creating such a policy community that is able to shape governments' long-term agendas and pressure decision-makers can result in positive interactions that form the background knowledge needed to change the shared culture between the two countries from rivalry to friendship (Hemmer and Katzenstein 2002; Moon and Suh 2007).

Last, the problem of asymmetry in reciprocity can be moderated by solving the asymmetry in commitment and enforcement (Keohane 1984; Fearon 1998). Taking alliance as an example, the presence of transaction mechanisms (such as revision of negotiated agreements, compromise, and common history) permits benefits to converge and complement for mutual parties, while expectations tend 
to be ignored or distorted in strategic partnerships due to a shortage of transaction channels and mechanisms to bind commitments. With regards to facilitating institutional building between the ROK and China, formalizing a mutual defense treaty has not been a feasible option mainly due to China's policy of non-alliance, the lack of a common source of threat, and ROK's ties with the U.S. Likewise, joining a China-led multilateral security platform, like the Shanghai Cooperation Organization (SCO), has not been a viable choice for the ROK deeply embedded in the Western liberal order (U.S. Department of Defense 2018b). ${ }^{6}$ In this light, the ROK-China partnership framework has not yet succeeded in legalizing each parties' strategic commitments in issues of high politics. However, in the common but fragile domain of the strategic cooperation on the Korean Peninsula, a process of binding China and enmeshing it into normative international diplomacy should be continued on the part of South Korea. The potential to enforce reputation costs can ensure some degree of commitment, and increasing China's commitment to longer term reputational considerations can in effect educate both parties' behavioral tendencies and align preferences. Various commitments made between both parties could be documented so that unit-level variables (for instance, leadership change) do not tarnish matters of mutual agreements.

\section{ACKNOWLEDGEMENT}

The author wants to thank the three anonymous reviewers for their helpful comments.

\section{REFERENCES}

Checkel, Jeffrey T. 1999. "Norms, Institutions, and National Identity in Contemporary Europe." International Studies Quarterly 43(1), 83-114. Chen, Gong. 2018. "Benefits of Korean Unification Likely to be Internal." Global Times (June 18). Accessed at https://www.globaltimes.cn/content/1107401. shtml (March 24, 2021).

Chidley, Colleen. 2014. "Towards a Framework of Alignment in International

\footnotetext{
${ }^{6}$ To date, South Korea has also shied away from accepting China's 'new security concept' as a global norm.
} 
Relations." Politikon 41(1), 1413-57.

Choi, Jong Kun. 2015. "Crisis Stability or General Stability? Assessing Northeast Asia's Absence of War and Prospects for Liberal Transition." Review of International Studies 42(2), 287-309.

Choi, Jong Kun and Chung-in Moon. 2010. "Understanding Northeast Asian Regional Dynamics: Inventory Checking and New Discourses on Power, Interest, and Identity." International Relations of the Asia-Pacific 10(2), 343-372.

Chung, Jaeho. 2011. Jung-gug-eul Gominhada [Contemplating China] (Seoul: Samsung Economic Research Institute). . 2012. "Korean Views of Korea-China Relations: Evolving Perceptions and Upcoming Challenges." Asian Perspective 36(2), 219-236. Chung, Jae-heung. 2017. Hanjung Sojangpa Hagjadeul-i Balabon Hanbando Anboisyu [ROK-China Scholar's Views on Korean Peninsula Security Issues]. Sungnam, Sejong Institute.

Chung, Kyung-young. 2019. "Building a Peace Regime on the Korean Peninsula." The Korean Journal of Defense Analysis 31(4), 477-500.

Deng, Yong. 2007. "Remolding Great Power Politics: China's Strategic Partnerships with Russia, the European Union, and India." Journal of Strategic Studies 30(4), 863-903.

Deng, Yuwen. 2013. "China Should Abandon North Korea." The Financial Times (February 27), Accessed at https://www.ft.com/content/9e2f68b2-7c5c-11e299f0-00144feabdc0 (March 24, 2021).

Dittmer, Lowell. 1999. Learning and the Reform of Chinese Foreign Policy. Singapore: World Scientific.

Dong, Xiangrong. 2019. "Shibie Chaoxianbandao de anquan kunjing yu fei anquan kunjing [Deciphering Security Dilemma and Non-Security Dilemma on the Korean Peninsula]." Dongbeiya Luntan [Northeast Asia Forum] 1, 102-115.

Fearon, James D. 1995. "Rationalist Explanations for War." International Organization 49(3), 379-414. . 1998. "Bargaining, Enforcement, and International Cooperation." International Organization 52(2), 269-305.

Friedberg, Aaron L. 2005. "The Future of U.S.-China Relations: Is Conflict Inevitable?” International Security 30(2), 7-45.

Fukao, Kyoji, Inui, Tomohiko, and Kwon, Hyeog Ug. 2017. "The Economic Impact of Korean Reunification on Major Trade Partners.” Emerging Markets Finance and Trade 53(11), 2476-2504.

Gilpin, Robert. 1981. War and Change in World Politics. Cambridge: Cambridge 
University Press.

Global Times. 2019. "Chinese, Russian Presidents Hold Talks" (April 26), Accessed at https://www.globaltimes.cn/content/1147599.shtml (March 24, 2021).

Goldstein, Avery. 2003. "An Emerging China's Emerging Grand Strategy: A Neo-Bismarckian Turn?" In John Ikenberry and Michael Mastanduno ed., International Relations Theory and the Asia-Pacific. New York, Columbia University Press.

Grieco, Joseph M. 1998. "Anarchy and the Limits of Cooperation: A Realist Critique of the Newest Liberal Institutionalism." International Organization 42(3) (Summer), 485-507.

Haas, Peter M. 2005. Epistemic Communities, Constructivism, and International Environmental Politics. London: Routledge.

Hemmer, Christopher and Peter J. Katzenstein. 2002. "Why Is There No NATO in Asia? Collective Identity, Regionalism, and the Origins of Multilateralism." International Organization 56(3), 575-607.

Hopmann, Terrence. 1996. The Negotiation Process and the Resolution of International Conflicts. Columbia: University of South Carolina Press.

Hwang, Jaeho. 2014. "The ROK's China Policy Under Park Geun-hye: A New Model of ROK-PRC Relations." International Journal of Korean Unification Studies 23(1), 103-130.

Ikenberry, John. 2000. After Victory: Institutions, Strategic Restraint, and the Rebuilding of Order After Major Wars. New Jersey: Princeton University Press.

Jervis, Robert. 1978. “Cooperation under the Security Dilemma," World Politics 30(2), 167-214. . 1999. System Effects: Complexity in Political and Social Life. New Jersey: Princeton University Press.

Johnston, Alastair Iain. 2013. "How New and Assertive is China's New Assertiveness." International Security 37(4) (Spring), 7-48.

Kang, David C. 2010. East Asia before the West: Five Centuries of Trade and Tribute. New York: Columbia University Press.

Kavalski, Emilian. 2018. "The Guanxi of Relational International Affairs." Chinese Political Science Review 3(3), 233-41.

Keohane, Robert. 1982. "The Demand for International Regimes." International Organization 36(2), 325-55. . 1984. After Hegemony: Cooperation and Discord in the World Political Economy. Princeton: Princeton University Press.

Khong, Yuen Foong. 2013. "The American Tributary System." The Chinese 
Journal of International Politics 6(1) (2013), 1-47.

Kim, Heung-kyu. 2012. "Enemy, Homager or Equal Partner? Evolving Korea-China Relations.” Journal of International and Area Studies 19(2) (December), 47-62.

Kim, Taeho. 2008. "An Emerging ‘Strategic Partnership' Between Beijing and Seoul? Myths and Realities.” The Journal of East Asian Affairs 22(2) (Fall/Winter), 97-121.

Korea Chamber of Commerce and Industry. 2020. "Je ilcha Daehansang-ui Tongsang Poleom Gaechoe [First KCCI Trade Forum Convened]" (June 12)" Accessed at http://www.korcham.net/nCham/Service/Economy/appl/ PhotoNewsDetail.asp? pageno=1\&SEQ_NO_C020=4047\&searchField=TI TLE\&searchText $=\% \mathrm{C} 1 \% \mathrm{~A} 61 \% \mathrm{C} 2 \% \mathrm{~F} 7+\% \mathrm{~B} 4 \% \mathrm{~EB} \% \mathrm{C} 7 \% \mathrm{D} 1 \% \mathrm{BB} \% \mathrm{~F} 3 \% \mathrm{C} 0$ \%C7+\%C5\%EB\%BB\%F3+\%C6\%F7\%B7\%B3 (March 24, 2021).

Korea International Trade Association (KITA). 2020. "Korea Trade Statistics-Of Specific Country.” Accessed at https://stat.kita.net/stat/world/major/ KoreaStats14.screen (March 24, 2021).

Kristensen, Hans. 2020. "China's New DF-26 Missile Shows Up at Base in Eastern China." Federation of American Scientists. Accessed at https://fas. org/blogs/security/2020/01/df-26deployment/ (March 24, 2021).

Lampton, David M. 2013. "A New Type of Major-Power Relationship: Seeking a Durable Foundation for US-China Ties." Asia Policy 16, 51-68.

Lee, Changhyung and Youngjune Chung. 2020. "Denuclearization-Peace Regime on the Korean Peninsula: How Should ROK and China Cooperate?" The Korean Journal of Defense Analysis 33(1), 19-39.

Lee, Sangkuk. 2013. "The ROK-PRC Joint Statement of the Future Vision \& Its Implications for Korea's Policy toward China.” KIDA ROK Angle 91 (November 5). Accessed at https://www.kida.re.kr/frt/board/frtPcrmBoard Detail.do?sidx=366\&idx=99\&depth=4\&searchCondition=auther\&search Keyword=sang\&pageIndex=2\&lang=kr (March 21, 2021).

Legro, Jeffrey W .2007. "What China Will Want: The Future Intentions of a Rising Power." Perspectives on Politics 5(3), 515-534.

Li, Bin. 2016. "Sadeuga nah-eun hanjung anbo dillemaleul puneun haebeob [Solving the ROK-China Security Dilemma]" The Kyunghyang Shinmun (August 3). Accessed at http://news.khan.co.kr/kh_news/khan_art_view.html? art_id=201608032111005 (March 24, 2021).

Liao, Nien-Chung Chang. 2016. "The Sources of China's Assertiveness: The System, Domestic Politics or Leadership Preferences?” International Affairs 92(4), 817-833.

Liu, Ruonan and Liu, Feng. 2017. "Contending Ideas on China's Non-Alliance 
Strategy." The Chinese Journal of International Politics 10(2), 151-171. Liu, Yeting, Cui, Yue, and Xiao, Xiao. 2019. "Zhongguo Waijiao Weishenme Jieban Bujiemeng? [Why does China Engage in Partnerships, but Not Alliances?]” People's Daily Online (November 16). Accessed at http:// politics.people.com.cn/n1/2019/1116/c429373-31458749.html (March 24, 2021).

Medeiros, Evan S. 2009. China's International Behavior: Activism, Opportunism, and Diversification. RAND Corporation, Santa Monica CA, 82-86.

Michalski, Anna and Zhongqi Pan. 2017. Unlikely Partners? China, the European Union and the Forging of a Strategic Partnership. London: Palgrave.

Ministry of Foreign Affairs of the PRC. 2016. "Wang Yi: Asia-Pacific Countries should Together Strive for Three Goals.” (June 2). Accessed at https://www. fmprc.gov.cn/mfa_eng/zxxx_662805/t1369741.shtml (March 24, 2021). . 2019. "Wang Yi Meets with Diplomatic Envoys of Eurasian Countries to China and Attends Friendly Exchange Activities.” Accessed at https://www.fmprc.gov.cn/mfa_eng/zxxx_662805/ t1720998.shtml (March 24, 2021).

Ministry of Foreign Affairs of the ROK. 2018. South Korea Diplomatic White Paper. Seoul: MOFA.

Ministry of Trade, Industry and Energy of the ROK. 2020. "Export-Import Trends." Accessed at http://www.index.go.kr/potal/main/EachDtlPage Detail.do?idx_cd=1066 (March 24, 2021).

Missile Defense Project. 2020. "Missiles of China." Missile Threat, Center for Strategic and International Studies (CSIS). Accessed at https://missilethreat. csis.org/country/china (March 24, 2021). . 2020. "Missiles of South Korea." Missile Threat, Center for Strategic and International Studies (CSIS). Accessed at https:// missilethreat.csis.org/country/south-korea (March 10, 2020).

Mission of the PRC to the European Union. 2014. "Speech by H.E. Wen Jiabao, Premier of the State Council of the People's Republic of China." Accessed at http://www.chinamission.be/eng/zt/t101949.htm (March 10, 2020).

Moon, Chung-in and Seung-won Suh. 2007. "Burdens of the Past: Overcoming History, the Politics of Identity, and Nationalism in Asia." Global Asia 2(2), 33-49.

Morrow, James D. 1991. "Alliances and Asymmetry: An Alternative to the Capability Aggregation Model of Alliances." American Journal of Political Science 35(4): 904-933.

Park, Hwee-rak. 2015. “Hanjung Jeonlyagjeog Hyeoblyeog Dongbanjagwangye'ui Gidaewa Hyeonsil Gan Gyeogcha [Expectation and Reality Regarding the 
'Strategic Cooperation and Partnership Relationship' Between China and South Korea]". Xin Asia 22-4, 60.

People's Daily Overseas Edition. 2018. "Zhenxi Bandao Laizhibuyi de Zhuanyuan

Qiji [We Should Treasure the Momentum on the Korean Peninsula]." (May 19).

Powell, Robert. 1999. In the Shadow of Power: States and Strategies in International Politics. Princeton, NJ: Princeton University Press.

Quan, Li and Ye Min. 2019. "China's Emerging Partnership Network: What, Who, Where, When and Why." International Trade, Politics and Development $3(2)$.

Ryu, Seung-hee. 2020. "2020 Nyeon Gugnae Suchul-ui Juyo Isyu [Major Issues in Domestic Exports in 2020].” Hyundai Research Institute (HRI) Report (March 6). Accessed at http://hri.co.kr/mobile/Viewreport.asp?numIdx= 30183\&firstDepth=1\&secondDepth=1\&thirdDepth=\#none (March 5, 2021). Schweller, Randell. 1994. "Bandwagoning for Profit: Bringing the Revisionist State Back In.” International Security 19(1), 72-107.

Shin, Gi-Wook. 2010. One Alliance, Two Lenses: U.S.-Korea Relations in a New Era. Stanford CA, Stanford University Press.

Shin, Gi-Wook, Izatt, Hilary and Rennie Moon. 2016. "Asymmetry of Power and Attention in Alliance Politics: The US-Republic of Korea Case." Australian Journal of International Affairs 70(3), 1-18.

Snyder, Glenn H. 1984. "The Security Dilemma in Alliance Politics." World Politics 36(4), 466-467.

Snyder, Jack. 2013. Myths of Empire: Domestic Politics and International Ambition. Ithaca: Cornell University Press.

Song, Young-gwan. 2020. "Hwagsandoeneun Segye Muyeog Jilseoui Bulhwagsilseong-gwa Hangug-ui Jeongchaeg daeeung [Uncertainty in World Trade Order Diffusion and ROK's Policy Response]" Korea Development Institute (KDI) Report 98. Accessed at https://www. kdi.re.kr/research/subjects_view.jsp?pub_no=16433\&pg=1\&pp=10\&mc $\mathrm{d}=001003001$ (March 24, 2021).

Strüver, Georg. 2017. "China’s Partnership Diplomacy: International Alignment Based on Interests or Ideology." The Chinese Journal of International Politics 10(1), 31-65.

Sun, Degang. 2020a. "China's Partnership Diplomacy in the Middle East." Contemporary International Relations 6. . 2020b. "China’s Partnership Diplomacy in the Middle East." The Asia Dialogue (March 24, 2020). Accessed at https://theasiadialogue. com/2020/03/24/chinas-partnership-diplomacy-in-the-middle-east/ 
(March 24, 2021).

Tang, Shiping. 2009. “The Security Dilemma: A Conceptual Analysis.” Security Studies 18(3), 587-623.

The Blue House. 2017. "The President Holds Summit with Chinese President Xi Jinping.” (July 6) Accessed at http://english1.president.go.kr/Briefing Speeches/Briefings/51 (March 24, 2021).

The Korea Herald. 2017. "Korea's Economic Dependence on China Stirs Worries about Risks." (August 18).

The Korea Herald. 2018. "U.S. Urges Korea to Speak Out on China Sea Dispute" (July 21).

U.S Department of Defense. 2018a. "Summary of the National Defense Strategy of the United States of America: Sharpening the American Military's Competitive Edge.” Accessed at https://dod.defense.gov/Portals/1/Documents/ pubs/2018-National-Defense-Strategy-Summary.pdf (March 24, 2021). - 2018b. "Indo-Pacific Strategy: Preparedness, Partnerships, and Promoting a Networked Region. (July 1).

Vaughn, Bruce. 2007. "U.S. Strategic and Defense Relationships in the Asia-Pacific Region.” Congressional Research Service (CRS) Report for Congress (January 22).

Wilkins, Thomas S. 2008. "Russo-Chinese Strategic Partnership: A New Form of Security Cooperation?” Contemporary Security Policy 29(2), 361-362. . 2012. "Alignment, Not 'Alliance'-the Shifting Paradigm of International Security Cooperation: Toward a Conceptual Taxonomy of Alignment." Review of International Studies 38(1), 53-76.

Womack, Brantly. 2006. China and Vietnam: The Politics of Asymmetry. Cambridge: Cambridge University Press.

Wu, Xinbo. 2018. "China in Search of a Liberal Partnership International Order." International Affairs 94(5), 995-1018.

Xinhua News Agency. 2014. "Jieban Bujiemeng: Zhongguo Huoban Bianshijie [Partnership without Alignment: China's Partners Transcend Global]" (December 23). Accessed at http://www.gov.cn/xinwen/2014-12/23/ content_2795587.htm (March 24, 2021).

. 2019. "Xi Meets ROK president, Calls for Advancing Bilateral Ties.” (December 23). Accessed at http://www.xinhuanet. com/english/2019-12/23/c_138652735.htm (March 24, 2021).

Yan, Xuetong. 2013. Lishide Guanxing [Inertia of History]. Beijing: CITIC Press Corporation.

Yonhap News. 2014. "Sijinping: Asiasinloehoeuileul Anbohyeoblyeoggigulo Mandeulja [Xi Jinping: Let's Make CICA a Security Cooperation 
Organization]” (May 21). Accessed at https://www.yna.co.kr/view/AKR 20140521103700089 (March 24, 2021).

Yu, Sang Cheol. 2015. "Hangug-i Jung-gug-e Gyeongsadwaessneunga [Is South Korea Tilted Towards China?]" The Joongang Ilbo (November 4). Accessed at https://news.joins.com/article/18999013 (March 24, 2021).

Zhan, Debin and Lee, Hun Kyung. 2012. "Chinese People's Understanding of the Korean Unification Issue." Asian Social Science 8(3), 63-74.

Zhang, Rui. 2016. "Shilun Zhongguo Huoban Guanxi Wangluode Zhengzhi Anquan Xiaoying [Chinese Partnership Network: Its Political and Security Effects]" Guoji Guancha [International Observation] 5, 40-58.

Zhou, Yiqi. 2017. "China's Partnership Network Versus the U.S. Alliance System: Coexistence or Conflict?" China Quarterly of International Strategic Studies 3(1), 1-18.

[Received Jan 25, 2021; Revised Mar 9, 2021; Accepted Mar 11, 2021] 